\title{
Ethically inclined models of authorship and lyric subjectivity in the poetry of Adília Lopes
}

\author{
Andrzej Stuart-Thompson \\ University of Oxford
}

Abstract: Adília Lopes' gender-conscious and other-orientated poetry expresses ethical concerns. The "inclined" and non-erect perspective of her lyric "I" (which accords with the concept of "inclination" coined by Italian feminist philosopher Adriana Cavarero), together with her experimentation with an "aesthetics of care" (akin to that proposed by eco-feminist scholar Josephine Donovan), engender texts which are sites of ethical encounters between author and reader. Meanwhile, her models of authorship and lyric subjectivity are imbued with transformative ethical implications, through their revelation (and redemption of) culturally suppressed and philosophically disparaged vulnerabilities that are common to both the human and the non-human conditions.

Keywords: Ethics, inclinations, authorship, lyric poetry, subjectivity, eco-feminism, Adília Lopes

Resumo: A poesia de Adília Lopes, com sua expressa consciência de gênero e alteridade, demonstra preocupações éticas. A perspectiva "inclinada" e não-ereta de seu "eu" lírico (em referência ao conceito de "inclinação" cunhado pela filósofa feminista italiana Adriana Cavarero), combinada a suas experimentações ao redor de uma "estética do carinho" (esta, afinada com marcos teóricos da ecofeminista Josephine Donovan), engendra textos que se constituem como espaços de encontro ético entre autor e leitor. Ao mesmo tempo, seus modelos de autoria e subjetividade lírica são imbuídos de implicações éticas transformadoras, através da revelação (e redenção) de vulnerabilidades 
culturalmente suprimidas e filosoficamente menosprezadas, comuns às condições humana e não humana.

Palavras-chave: Ética, inclinações, autoria, poesia lírica, subjetividade, eco-feminismo, Adília Lopes

O meu eu, o eu, é frágil, muda e fica, é uma planta. Poem in Irmã Barata, Irmã Batata (2010) (Lopes, 2014: 416)

\section{Introduction}

The poetry of Adília Lopes is invested with several ethical dimensions, which are inextricably linked with her idiosyncratic and interrelated paradigms of authorship and lyric subjectivity. Gender-consciousness and the redressing of phallogocentrism is the first of these dimensions, as her writing is explicitly inscribed within a female genealogy, challenging the masculinization of literary authority and genius throughout Western history (cf. Battersby 1989). This inscription of femaleness in her work is allied to a process whereby canonical literary influences are de-hierarchized, and lyric poetry is desacralized. ${ }^{1} \mathrm{~A}$ second dimension is the charitable orientation of her poetry towards alterity; the lyric "I" both gives voice to, and is open to being constituted by, others, both human and non-human, and even inanimate matter. ${ }^{2}$ Despite its re-enactment of life's everyday cruelties, and the pervasive attention it pays to the grotesque and the comical, her work nevertheless resonates with notions of care, empathy and vulnerability. ${ }^{3}$ Vulnerability, an attitude under threat of suppression in contemporary patriarchal military-capitalist Western culture, is recuperated in Adília's work, not only in the sense of its being freed from purely negative (and often gender-stereotyped) associations, but also in so far as it becomes a powerful metaphor for openness. ${ }^{4}$ Ultimately, I contend that the ethical quality of Adília's poetry, present in all of the aforementioned elements, comes to light most completely in two of its foremost, all-embracing features: firstly, the "inclined" (that is to say, other-orientated) and non-erect perspective of Adília's lyric 
"I", to use the concept of "inclination" coined by Adriana Cavarero (2016), in whose "critique of rectitude" Adília's poetry seems to participate; and secondly, her experimentation with an "aesthetics of care", proposed by eco-feminist scholar Josephine Donovan (2016). In this way, her texts are sites of ethical encounters between author and reader, while her models of authorship and lyric subjectivity are imbued with transformative ethical implications.

\section{Feminist and Queer Inclinations: Critiquing Rectitude, Valorising Obliqueness}

As Adriana Cavarero explains, inclination - whether figured geometrically as a slant vis-à-vis the vertical axis, or else in affective terms as the openness of human desire and affect in relation to others - is a concept which has been feminised throughout the history of Western philosophy (Cavarero 2016): in the former sense, it is related with the oblique posture of pregnancy, and the mother's leaning-over the infant, while, in the latter, it subtends the purported propensity of women to lasciviousness and outpourings of emotion. The tradition of privileging inclination's opposite, rectitude, is nascent in Greek philosophy in Plato's myth of the cave. Here, the chained and curled up prisoners, with their false visions, are pitted against the philosopher who, following the road that leads upwards towards the sun, the "zenith of the visible", learns to straighten himself up "according to the perpendicular line of the truth" (idem: 54). The supposedly positive nature of verticality henceforth recurs in Western thought in metaphors of a masculine tenor. These include the medieval image of the genealogical tree that phallically springs up from Adam (idem: 58), and the pervasive notion of the upward, heaven-bound flight of the mind, transcending the confines of the body to rise above the feminine earth, in discussions of male artistic genius (cf. Battersby 1989). Indeed, the very advent of civilisation itself is, for many thinkers, including Freud, prefigured in the adoption of an erect posture by our Pleistocene ancestor homo erectus (cf. Freud 1961: 99, n.1). Kant finally makes his exemplary intervention in the history of this idea with his repudiation of the prostrate dependency of the infant, and his development of an individualist ontology founded upon the notion of the free, autonomous and morally upright self. 
Meanwhile, Cavarero's feminist revision of the term "inclination" throws up its potential to de-stabilise the centrality of the vertical, self-sufficient self, since - as Hannah Arendt observed - "every inclination turns outward, it leans out of the self in the direction of whatever may affect me from the outside world" (Cavarero 2016: 5-6). I situate Adília's poetry resolutely within this feminist reappraisal of the positive value of relational ontology. Not only does Adília manifest suspicion towards rectitude ("Desconfio/ de quem escreve/ direito/ por linhas direitas" [Lopes 2014: 474]), but she also leans out of herself even to the point of allowing her authorial voice to be infiltrated quite literally by other people's, as in the untitled poem whose opening lines read "Poesia é:/ canto/ conto/ e conta" from the 2003 collection César a César (Lopes 2014: 494-495), in which a child's uncomplicated definition of poetry is subsequently used to rephrase and clarify this typically Adilian aphoristicparonomastic construction. Furthermore, Adília regularly deploys corporeal imagery to illustrate the flexibility of her authorial voice, assuming unconventional shapes and inclining foetally over itself:

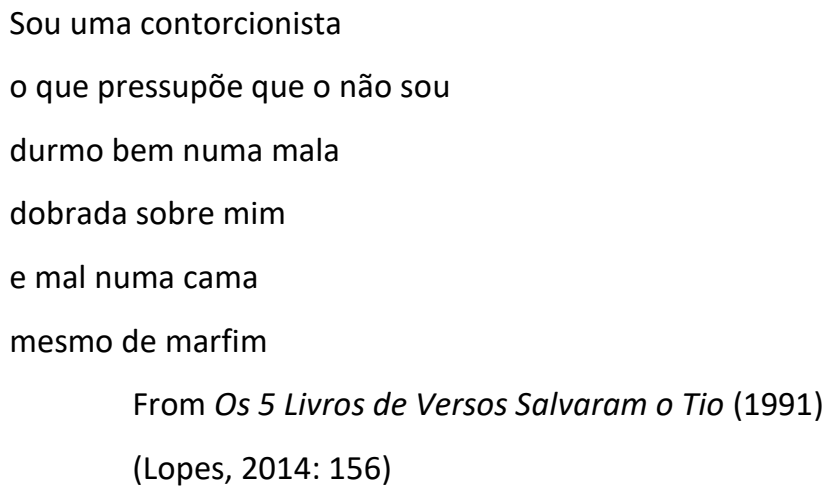

The image of the "marble bed", or catafalque, calls to mind the pantheon of poets, where Adília would "sleep badly" among the dead poets of tradition. Rather than assure herself a place there by conforming to conventional poetic styles sliding comfortably into the literary furniture, with its well-worn grooves, shaped by the repeated imprints of past practitioners such as Bernardim Ribeiro (who is addressed in this poem's second half in his guise as the archetypal rhyming poet) Adília prefers to adopt a contorted posture. Rhyme, as the ready guarantor of poetry's phonic harmony and internal unity, does not feature in Adília's regular 
inventory of formal devices, and when it does appear, as in this poem, it is used ironically (with the rhyming of "mim"/"marfim" in lines 4 and 6 being immediately followed by a remark on how sad rhyme is, II.7-8, "nada é tão triste/ como uma rima"). For Adília, conforming to the conventions it represents would indeed be tantamount to a figurative death within the static confines of tradition.

In order to consider Adília's apprehension of the additional barriers inhibiting artistic freedom and self-awareness that are posed by traditional gender norms, and which will ultimately be overcome in her poetic output through an assertion of the value of inclination, it is helpful to examine the poem entitled 'Um quadro de Rubens' from her debut poetry collection Um Jogo Bastante Perigoso (1985). In this poem, we infer that the first-person speaker may be in a museum, trying to catch a glimpse of a Rubens painting, which is hidden from view by a crowd of people with whom the speaker competes for a vantage point. Nonetheless, the eponymous Rubens painting never appears in the entire course of the poem. What is staged is less an ekphrastic competition between painting and poetry, which we might be led to expect from the poem's title, and rather a dilemma about where the speaker may position herself and her body phenomenologically in relation to other bodies.

The speaker is trapped "comoprimida/ num ajuntagente", with the two neologisms which shrink the words "como" and "oprimida" (and probably also "comprimida"), and "ajuntar" and "gente" respectively, capturing the tautness of space available in the museum through the tautness implied in these opening words and line lengths (II.1-2), between six and seven syllables, which are short relative to the following five lines (II.3-7) which all attain or exceed thirteen syllables. A pair of female bodies block the speaker's way: firstly, a woman with a cigarette who is "projetada/ para cima de mim" (II.5-6 [my emphasis]), calling to mind the cigarettesmoking femme fatales of cinema; secondly, a "sex symbol", amplified mathematically via homotetia, whose clothing boasts an excessive number of straps, calling to mind bill-board enlargements of women's bodies in adverts for lingerie. Thus, the speaker of this poem finds herself confronted with an array of stereotyped visual representations of femininity, even before she ever has a chance to lay her eyes on the painting by Rubens, who it should be emphasised is famous for his 
provocatively plump and voluptuous depiction of the nude female form (see Figure 1 below); his art, elusively absent yet providing the coordinates around which the poem operates, stands for the pervasiveness of archetypes of female beauty that are designed to gratify the male gaze. The overwhelming oppression of such body images instils in the speaker the desire to flee. However, the group hems her in; her escape route is confined to the vertical axis:

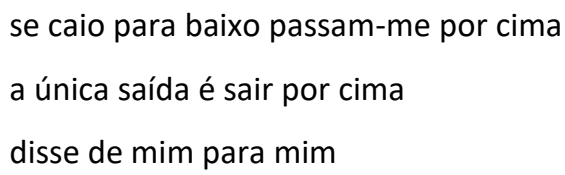

The verbal phrases "cair para baixo" and "sair por cima" are redolent of Christian symbolism concerning the (downward) fall of mankind and the (upward) assumption of the Virgin Mary, the latter being depicted in Rubens' painting (see Figure 2 below), deepening the symbolic significance of verticality within the poem, by evoking its moral connotations. It is worth noting that, in this segment, the bodies inhabiting the space of the poem are depicted as being incapable of relating to one another except along straight lines.

FIGURE 1:

The Three Graces.

Rubens, Peter Paul (1577-1640).

Oil on oak panel. c. 1630-35.

Museo del Prado, Madrid.

$221 \mathrm{~cm} \times 181 \mathrm{~cm}$. Painting.

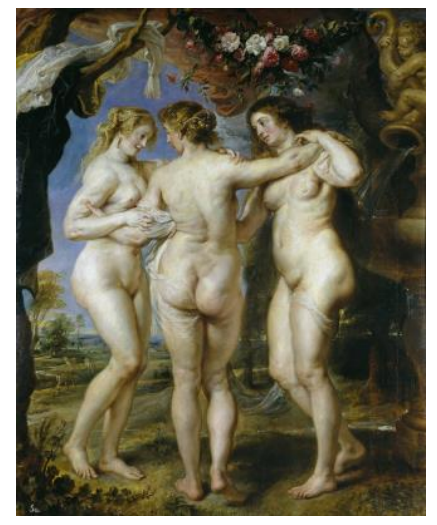

\section{FIGURE 2:}

The Assumption of the Virgin. Rubens, Peter Paul (1577-1640). Oil painting, on altar. c. 1625-26. Cathedral of Our Lady, Antwerp. $490 \mathrm{~cm} \times 325 \mathrm{~cm}$. Painting.

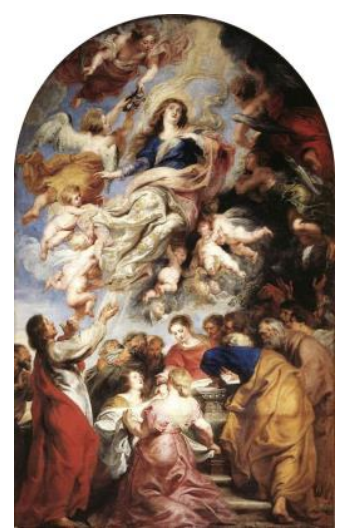


Next, discovering that the people of the "ajuntagente" are literally "feitas aos degraus", she attempts to climb them as she would a staircase, causing her to undergo a process of alienation from herself as she ascends the ladder of conformity. Adília's poem thereby depicts the struggle of women who have, historically, been disproportionately afflicted by a sense of aesthetic objectification, deviating from the masculine neutral. It is worth noting that Adília is by no means simplistic on this point: both genders suffer from the constraints of normativity, whereby people are labelled on the basis of gendered assumptions, for example about the pitch of their voice, as the grotesquely comical reference to the stepped-upon (and possibly misidentified) woman who lets out a highpitched scream, but could just as easily be a male countertenor, makes evident.

The lexis of painterly images continues in the speaker's closing self-appraisal as "intocável", which could be yet another reference to the Virgin Mary, the woman who epitomises restraint from sexual interaction:

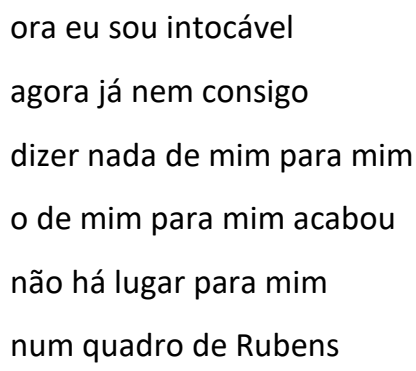

However, if she could not fit into the overtly sexualised categories of femininity portrayed by the cigarette-wielding woman or the sex symbol, then allotting herself into the only other category available to her, that of de-sexualised divinity, does little to help her get back in touch with herself (with the revisiting of the notion of "o de mim para mim", now annulled, "acabou") or to connect with other people for that matter. Adília thus portrays the conflict of the gender-conscious lyric self in coming to represent itself outside of the circumscriptions of cultural representations of femininity, which constitute a landscape, a Rubens painting, in which she does not see herself fitting. 
Returning to the theme of this poem in 'Body Art?' (Lopes 2014: 338), in which she explores the painful personal implications of weight consciousness, and, later still, in 'Os ricos são magros' (idem: 478), in which the speaker wryly comments that she has now put on enough weight to fit in a Rubens painting ("Engordei $43 \mathrm{Kg}$ de 86 para cá/ agora/ gorda como estou/ já caibo/ num quadro de Rubens") (idem: 479), Adília demonstrates her pervasive concern with gender normativity, even if the seriousness of the matter is punctuated at times with light-hearted humour. Sara Ahmed's work on Queer Phenomenology has reimagined queerness as a sexual disorientation; "compulsory heterosexuality operates as a straightening device" and "bodies become straight by "lining up' with lines that are already given" (Ahmed 2006: 23). In a broader sense, this notion of queerness applies also to anybody who does not fit gender norms, and in whom a feeling of discomfort is produced by not fitting with the straight lines of available identity positions. Yet, as Ahmed notes, how one faces the world, in Adília's case from a queer perspective of non-alignment with gender normativity, "means inhabiting different worlds" (2006: 68), thereby opening up the potential for new orientations and ethical alignments. Thus, Adília comes to inhabit a position of vulnerable disorientation, which becomes the mainstay of her poetic enterprise.

Adília's poem 'Inclina-se mais' (from Os Namorados Pobres, 2009), which references Pessoa's only female heteronym, Maria José the lovelorn hunchback, illuminates her adoption of inclination as a remedy to the alienation of author from poetic tradition, and as a catalyst for re-formulating the lyric self. ${ }^{5}$

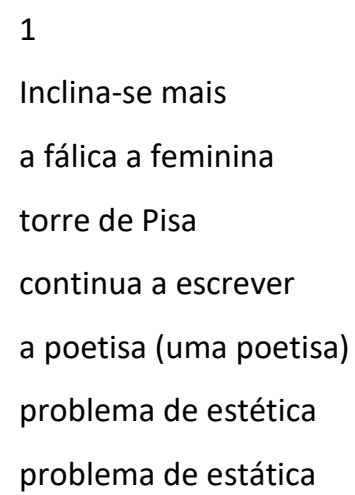




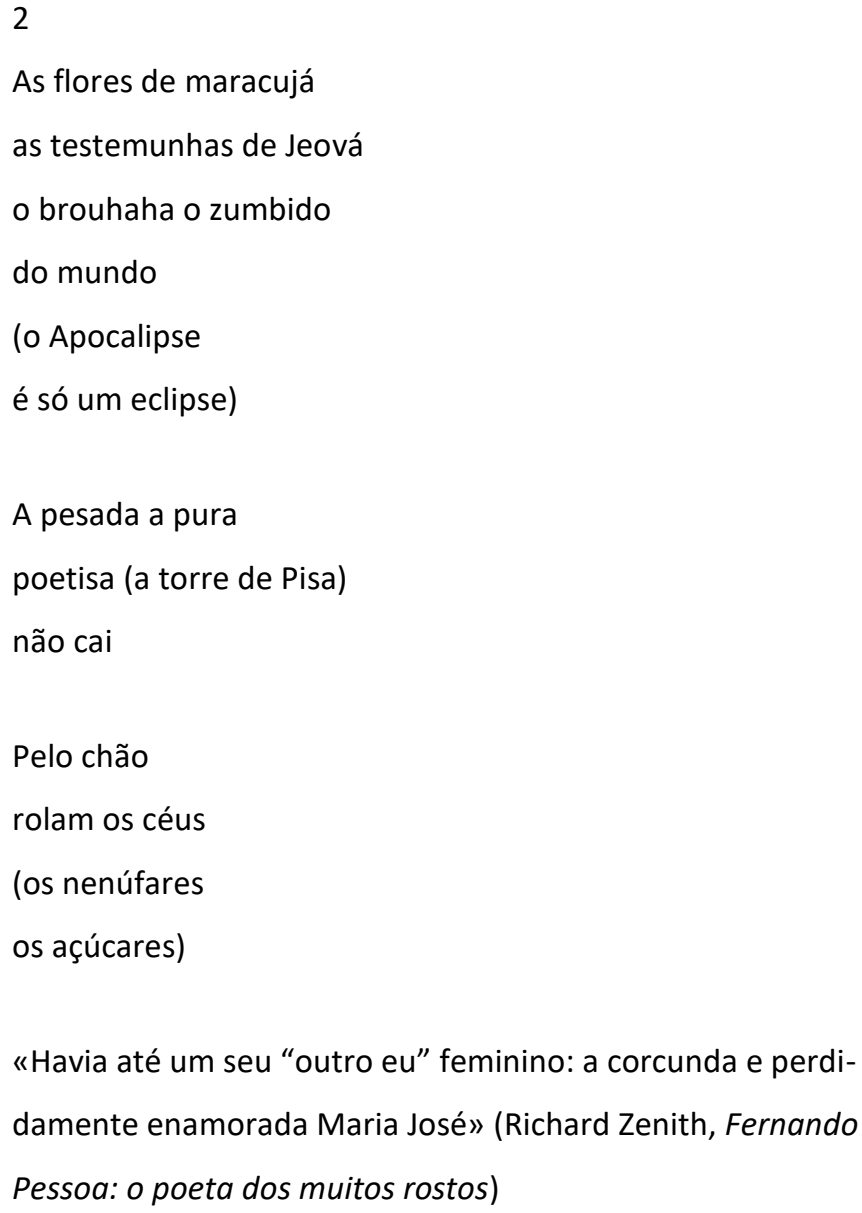

The poem's first section opens under the sign of androgyny with the image of the "feminine" yet "phallic" leaning Tower of Pisa. Indeed, the postscriptum reference to Pessoa's female heteronym, which we may be disposed to read as an invocation of Pessoa's celebrated project of depersonalisation, equally suggests Adília's own openness to using and dialoguing with both male-authored sources (including Bernardim Ribeiro, Camões, Pessoa, Ruy Belo and Herberto Helder) and female-authored ones (from Emily Dickinson and Sylvia Plath to Agustina Bessa-Luis, Sophia de Mello Breyner Andresen and Maria Teresa Horta). The resulting artistic product, symbolised architectonically, is an amalgamation of gendered perspectives - both of the culturally dominant one, and the submerged/emergent one. In this regard, it is worth noting that this poem is particularly invested in a re-inscription of the feminine into literary history, especially with the idea of the emergence and strengthening of female poetic lineage, from the conspicuous singularity of Pessoa's only female 
heteronym during the male-dominated Modernist period where often "women were still ventriloquially spoken by male-authored artistic creations" (Owen/ Pazos-Alonso 2009: 169), to the subsequent rise of the female poet as a fully-fledged category. This is suggested by the movement in line 5, from the definite article (heralding the lone poetess) to the corrective parenthesis, which uses the indefinite article (suggesting "one-among-many"). We might conjecture that the idea of female artistic genius is also underscored by this repetition of the anachronistic, gender-saturated word "poetisa", recalling the poem 'Vaidade' by modernist poet Florbela Espanca, in which she envisioned her assumption of the role of "Poetisa eleita" (Espanca 2012: 84) in a world inimical to the revelation of female artistic genius. The intertextual ties thereby established with Florbela further predispose the reader to understand the poem as a commentary on the place of women in the history of cultural production.

The paratactical construction of the first stanza implies a link between the everincreasing inclination of the tower ("Inclina-se mais") and the poet continuing to write; whether the link is causal, or else suggestive of a tension or conflict between the two clauses, remains at this point a question of enigma. If we read the completed stanza figuratively, then the inclination of the Tower of Pisa is apprehended by the poet as a "problema de estética/ problema de estática", perhaps seeking resolution. In the light of the aesthetic dilemma posed, which awakens an expectation in the reader for its being worked through, the second section opens all the more enigmatically, with the unprecedented use of surrealism and the juxtaposition of images of passion fruit flowers (the exotic), Jehovah's witnesses (unexpected visitors), and the buzzing commotion of the wider world. Perhaps the poem meta-textually and knowingly gestures towards the kind of chaos that this represents in the parenthesis of lines 5-6, suggesting that this surrealist reverie is only a temporary eclipse of the question of the ars poetica (the working through of an aesthetic difficulty) which the first section has prepared us for. Thus, the second section's second stanza returns us to the question of the Tower of Pisa and its inclination, yet this time the tower is subordinated as a means of describing the poetess herself. Given Adília's frequent deployment of the vocabulary of purity and virginity in reference to her poetic personality, it is tempting to see the description of "a pesada a pura/ poetisa" (my emphasis), who does 
not fall, as a self-portrait. The poem's second section, with its short three-line second stanza, thus continues to enact its own premise: that poetic enterprise is an act of creating improbable, leaning ("inclined") structures which nevertheless stand up on their own, just as the poetess stands up against the overbearing weight of the masculine tradition. Indeed, like the hunchback Maria José and the leaning Tower of Pisa, both of which are vulnerable to falling yet defy gravity, the poem itself is structurally top-heavy, with the first stanza containing seven lines, the second having six, the third, three, and the fourth, four.

Finally, the second section closes with its third and final stanza (the fourth stanza overall), which returns us to the realm of the surreal. Hélène Cixous's essay 'Sorties' (De Courtivron / Marks 1980: 90-98), in which she describes the cultural symbols of masculinity (the sun, the day, the head and the principle of intelligibility) and femininity (the moon, the night, the heart and the principle of sensitivity), provides us with a useful framework for understanding the poem's dénouement. Here, logic has been overthrown, with the toppling of the heavens, as the world literally turns upside-down in the phrase "Pelo chão/ rolam os céus", which evokes the set expression "rolar cabeças". Since the skies are the locus of the (masculine) sun, which is obscured by the (feminine) moon, their laying-low signifies a comprehensive re-visioning of the poetic landscape. If we consider that the poem enacts a solar eclipse, both through the eclipse of logic with the intrusion of surrealism (generating a movement of free association) and the eclipse of the god-like authority of the masculine canon through feminine poetic intervention, then the rolling of skies/heads depicted in the closing stanza could be read as a depiction of the toppling of phallogocentrism itself.

The enactment of a female artist's intervention into the literary canon, to appropriate the figure of the hunched Pessoan heteronym, under whose auspices the poem takes its inclined shape, suggests an overturning of literary history such that the literary landscape takes on new hues in the psychologically-liberated, uninhibited surrealist mode an apt style for figuring the way in which Adília's poetry implies an unshackling from gendered constraints. Not only this, but the poem also vindicates the value of impassioned inclinations figured in the feminine, since "a corcunda e perdidamente enamorada Maria José" stands for the principles of sensitivity and emotionality. The interpenetration of the two worlds - of surrealism, on the one hand, and of logic (in the form of the syllogism-driven 
ars poetica), on the other - evidences the fruitful cross-pollination of poetic idioms made possible by the poetics of inclination.

The following self-portrait by Adília returns to the subject of the Virgin Mary, the quintessential embodiment of maternal inclinations, in a more positive light:

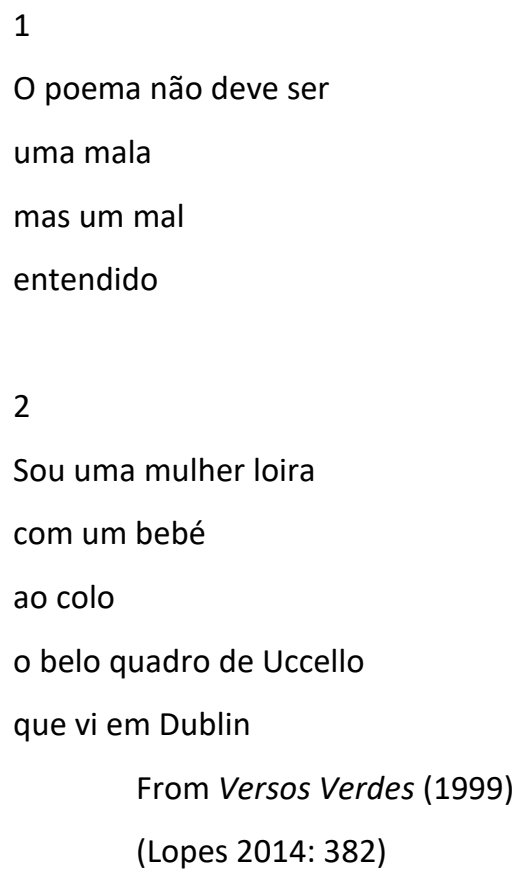

The Uccello painting (see Figure 3 below), one of the few by the artist to have survived, depicts the jovial baby Jesus reaching out over the edges of an illusory painted frame, as he is held on a slanted angle by the blond Virgin Mary, whose gaze is askew, caught in the attention of that which lies beyond the canvas and which has also aroused the interest of the baby. At the same time, Mary is depicted in an indeterminate state, somewhere between the human and the statuesque, tying in to Adília's interest in the material body, as well as the construction of poetic identity, like sculpture, as a work of art in itself. This is conveyed in the poem by the implication that Adília is figuring herself not only as the Virgin with the baby on her lap, but as the painting itself and the entirety of its contents: "Sou [....] o belo quadro/ que vi em Dublin". Thus she is both the mother - whose oblique gaze, if not her upright posture, betrays her receptivity to the instinctive motion of her dependent - and the vulnerable infant himself. Adília thus comes to embody the principle of symbiotic relations, emblematically portrayed in the Uccello painting. As the 
poem's first section seems to suggest, poetry is not a means to an end (as a suitcase is to a journey), but is rather an invitation to misunderstand things ("um mal-entendido"), or even to deconstruct the binary of good and evil by attempting to comprehend, and not merely exorcise or excoriate, ills ("um mal/ entendido"), an alternative reading emphasised through the enjambment. In other words, Adília's poetry is an invitation to re-appraise the world through misapprehending its common appearance and instead slanting our perspective, in order to perceive the implicatedness of self and other, just as the borderline between art and life itself is blurred in her work (as with the intrusion of autobiography ["que vi em Dublin"] in Adília's poem, and the seeming emergence of the baby Jesus, painted as though climbing out of the frame, from the Uccello painting).

\title{
FIGURE 3 (right):
}

Virgin with Child.

Uccello, Paolo (1397-1475).

Tempera on wood panel. c. 1440.

National Gallery of Ireland, Dublin.

$58 \mathrm{~cm} \times 37 \mathrm{~cm}$. Painting.

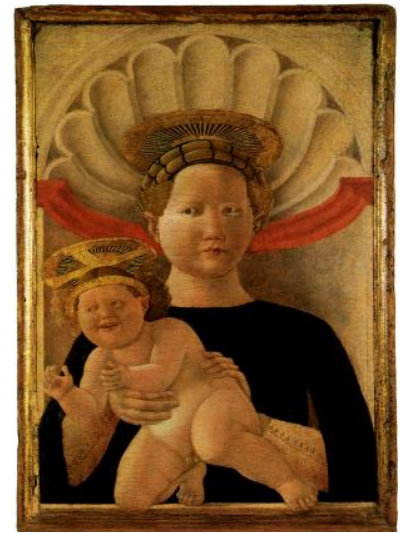

\section{The Slantwise Perspective of the Vulnerable}

Vulnerability, and its connection to wider societal issues, is a prominent feature of the following poem:

\author{
Tempestade \\ num copo \\ de água \\ tentar escrever \\ o texto é público \\ é privado \\ o texto é penico
}




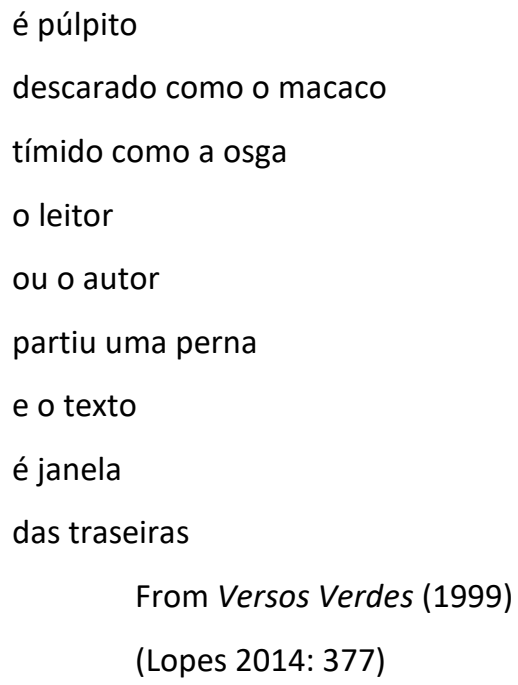

The poem opens with a storm in a teacup, apparently arising from the failed attempt to write, which is paradoxically productive of the poem itself; the poem's tone from the outset is therefore ironic and invested in the defiance of logic. This continues in the yoking of apparent opposites through poetic craft, such that the text can be both public and private, a private potty for the expulsion of excreta, at the same time as a pulpit for preaching words of wisdom to the wider world. Indeed, the shape of lines 6-9 means that the private is always-already framed by the public, just as equally the personal always lies at the heart of the political. Author and reader are also brought together in the co-production of meaning, in lines 11-13, with one or the other having "broken a leg", sharing a defenceless state. Furthermore, no hierarchy is implied between them, nor does the reader look to the text for an explication of the writer's intentions; rather both share the same slanted perspective. This slanted perspective on the world is implied by the asymmetry, the tilted centre of gravity, and the imbalance produced by a broken lower limb affecting only one half of the body.

The poem closes with the metaphor of the text as a rear window on the world, which, given the fact that the collection (Versos Verdes) features another poem entitled 'Psycho', almost inevitably situates this poem in relation to Alfred Hitchcock's film Rear Window (1954). In this film, the wheelchair-bound protagonist, Jeffries (James Stewart), turns his habits as a professional photographer to a more private kind of voyeurism, as he spends his days obsessively observing the lives of his neighbours across the courtyard. 
Looking into one rear window in particular, he becomes convinced, through interpreting various clues, that he is witnessing a wife-murderer covering his tracks. If Adília's poem - the artistic product - is like the Hitchcockian rear window, which serves as a metaphor for the cinema screen itself, then what seems to be implied is that the text is the device through which the private is seen in an act of imaginative interpretation, as well as the mechanism which brings reader and writer together in an ethical act, in the same way that Jeffries' vision through the window leads him to uncover a crime, as well as to inadvertently establish a bond with the murderer (Raymond Burr) himself, who at the film's climax returns Jeffries' gaze. Thus, the production and consumption of Adília's model literary text can be said to heal private wounds (one comes to literature already wounded, with a broken leg), while at the same time fostering a slanted perspective on the world which will reveal social ills in need of ethical address. What is vindicated is the slantwise perspective of the vulnerable, which in other of Adília's poems is figured as the trigger for a compassionate perspective on the world that refuses to objectify or to other.

It is worth noting that the conception of the text offered in this poem also conveys a sense of the text having independent agency; it is the form which, cheeky as a monkey and timid as a gecko, renders meaning indeterminate through the cheekiness and slipperiness of irony and a writerly destabilising of meaning: after all, given the lack of punctuation and the multiple potential referents for the creaturely adjectives, it could be that they refer just as much to the "leitor" and "autor", as to the text itself.

\section{Animal Vulnerability, (Eco-)Feminism and The Aesthetics of Care}

This ethical approach, emerging from a contemplation of human vulnerability, paves the way for an extension of care to other vulnerable beings, namely animals, which - as the monkey and gecko of the preceding poem indicate - have a significant presence in Adília's work. Turning now to the way in which her poetry resonates with an ethics of care towards animals, tied to their careful aesthetic representation in her work, it is useful to consider the theories of the eco-feminist writer Josephine Donovan. In her book The Aesthetics of Care: On the Literary Treatment of Animals (2016), she advocates an "experimental attentiveness" and "empathic mimesis" of animal behaviour (Donovan 2016: 73), in order to communicate 
their unique subjectivities as closely as possible, stripping away the distorting symbolic meanings the human mind has attached to them. As Mary Midgley has pointed out, such symbolism has deeply distorted our understanding of animals' actual behaviour. Such is the case for pigs, who "made the mistake [...] of being the sacred animal of Baal, which gave the Hebrews a bad opinion of them", causing them harm ever since, especially in the "servile and disreputable image that results from close confinement on a farm" (Midgley 2004: 214). The pig features in a poem from Le Vitrail La Nuit/ A Árvore Cortada (2006), alongside another animal who has suffered a bad reputation as a witch's familiar, the crow; Adília declares them her companions:

\author{
Sigo \\ o meu caminho \\ que é torto \\ Um corvo \\ me acompanha \\ e um porco \\ (Lopes 2014: 596)
}

As Eve Kosofsky Sedgwick has pointed out, the concept of besideness, which is evoked here in the use of the verb "acompanhar", is useful because "Beside permits a spacious agnosticism about several of the linear logics that enforce dualistic thinking: noncontradiction or the law of the excluded middle, cause versus effect, subject versus object" (Sedgwick 2003: 8). The Latin root of the word acompanhar, having to do with the sharing of bread ("com pão"), redoubles the sense of Adilia's convivial relationship with animals. In other words, the relationship of Adília's lyric "I" with non-human animals is one of reciprocity and mutual subject status. She deviates from the norm by following her twisted path, accompanied by the crow and the pig. While her invocation of these animals in a poem about crookedness is hard to disassociate from their pagan connotations, nevertheless the notion that the animals are beside her, rather than following or in some way subjugated by her, goes some way towards dispelling such (symbolic) connotations. 
Adília's deconstruction of animals' negative reputations, accrued in our habitual representations of them, continues in the following lapidary poem, in which the speaker summarily exposes and rejects the pejorative attitude towards both women and animals which underpins the use of names for female animals as insult terms:

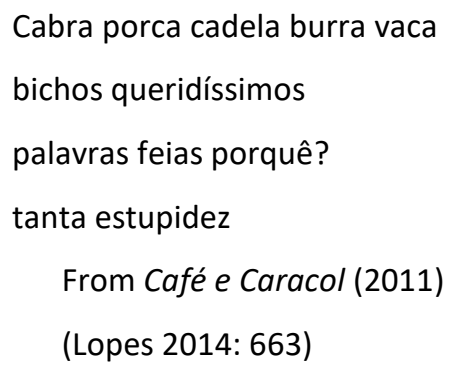

The link between feminism and eco-criticism emerges from the recognition of the way in which patriarchal logic objectifies both women and non-human animals, by divesting them of their respective subject positions, imagining them as the incarnations of rational man's most despised qualities (for example, dependency, epitomised in relations between mother and child; uncontrollable passion, as with the alleged lasciviousness of bitches; or the supposed slovenliness and greed of pigs), and by reifying them as commodities. Eschewing "the dominant 'I-it', 'sado-dispassionate' conception offered in the CartesianKantian constructions of Enlightenment modernity" (Donovan 2016: 73), Donovan offers in its place a "participatory epistemology - an 'I-thou' relationship" to creatures, who she recognises inhabit worlds of their own, have stories of their own to tell, and are deserving of respect. This belief appears to be emphatically endorsed by Adília in such prose pieces as 'Depois do holocausto, a barata Eva e a barata Adão comerão da maça', from Irmã Barata, Irmã Batata (2000) (Lopes 2014: 412), in which the speaker describes helping upturned cockroaches to right themselves, and 'Memória', from Andar a Pé (2013) (Lopes 2014: 673), in which she remembers enjoying a children's book which depicted cats at play while the owners were away, knocking a milk jug over a piano. ${ }^{6}$ The human proverb about "leite derramado" is divested of its negative connotations and literalised by the cat's mischief, which the speaker calls "delicioso". This emphasises the sustenance that can be taken from allowing animals to be animals, joyfully beholding the full expression of their alterity, and not asking them to conform to human norms of propriety or purvey purely symbolic 
meanings. Here indeed, Adília's cats are characterised through the bare minimum of details, in particular their action of knocking the milk jug, indicating a mimetic gesture. This does not necessarily imply the ethological transcription of a cat's behaviour. After all the recollection is not of any real cat, but rather of a story about cats, demonstrating that Adília never loses the sense of culture's perpetual mediating presence. However, it does seem to capture Donovan's broader sense of an "aesthetics of care", in that it valorises feline behaviour beyond any inconvenience ("leite derramado") it may cause for humans.

In her three 'autobiografias sumárias' (Lopes 2014: 71, 408, 418), which feature cats and cockroaches, Adília further inclines her definition of the lyric "I" beyond even the confines of human identity. She suggests that the interactions between human and nonhuman animals, through living together (which has an important autobiographical inflection, given that the author does indeed live with cats), already blur the species barrier between them, such that human identity is informed by animal identity. As Mary Midgley observes, because of the implicatedness of human life within animal life and vice-versa along these lines, "nature supplies no plain line" dividing up creatures who are and are not worthy of moral attention (Midgley 1983: 111). Animals are thus integral to Adília's lyric self, as much as the latter is a vehicle for exploring the former's peculiar subjectivities. The first of her 'autobiografias sumárias' formulates authorial identity in a metaphor deriving from the interaction between two non-human species:

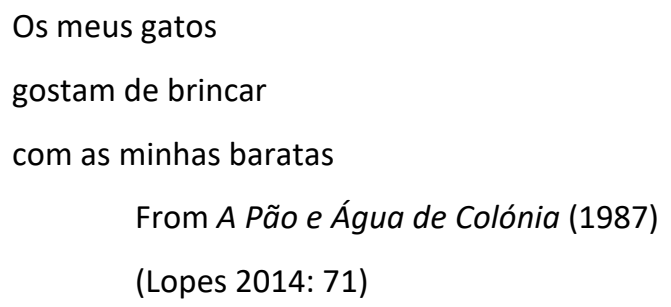

Adília emphasises the playfulness of the cats, at the same time as she evidences the playfulness of her own lyric voice. The choice of the verb "brincar", as opposed to say "torturar", reveals how this description is not exempt from irony; after all, playful cat behaviour is torture for cockroaches. In one and the same stroke Adília describes the cats' manner as well as her own, which is inspired by it; in other words, Adília's inclination towards animals implies the interpenetration of their subjectivities, generating new poetic 
possibilities. The poem's gender-consciousness is also noteworthy, since the dominant creature is figured in the masculine ("os meus gatos"), while the vulnerable one is feminine ("as minhas baratas"). This possibly alludes to how Adília's authorial voice grapples with the embattled position of female and Deleuzian minoritarian authors writing against the maledominated, masculine canon; the literary use of cockroaches almost inevitably evokes two such authors, Clarice Lispector (A Paixão Segundo G.H., 1964) and Franz Kafka (The Metamorphosis, 1915).

Yet, what is most significant, in terms of the "aesthetics of care", is the way in which Adília revisits the 'autobiografia sumária' twice in Irmã Barata, Irmã Batata (2000), not only to rescue the cockroaches from their victimisation, but also to evince a more tender portrait of the cats: in the second 'autobiografia sumária' (Lopes, 2014: 408), written in prose, the lyric "I" intervenes to prevent the cat, now figured in the feminine singular ("a gata do résdo-chão"), from playing with her cockroaches. The cat is further distanced from the speaker through the absence of the possessive adjective, as well as its re-assignment to another owner, perhaps the ground-floor porter, and yet this makes her ethical intervention in aid of the weaker species, curtailing the cruelty of others' pets, all the more socially significant. In the third 'autobiografia sumária' (Lopes, 2014: 418), the cats, once more featuring in the masculine plural, "já deixaram há muito tempo de brincar com as minhas baratas", and are now given names: "Ofélia", "Guizos" and "Dr. Morais". In a meta-textual gesture, the speaker explains that she is typing the poem on the computer, while she has not seen Guizos for three days, engendering a wistful tone as the speaker contemplates animal mortality. When read in succession, as we are encouraged to do by Adília's use of a numbered sequence in the titles, the pieces progress from using animals principally for their symbolic literary function to depicting them as living creatures in their own right, meriting concern beyond the world of literature.

Adília's poetic treatment of animals is thereby infused with an ethical concern for their wellbeing. Continuing in this vein, the following poem upbraids Clarice Lispector for her children's story A mulher que matou os peixes, where a woman tells a series of animal stories by way of seeking forgiveness for neglecting to feed her son's pet fish while she was busy writing books, killing them through forgetfulness: 


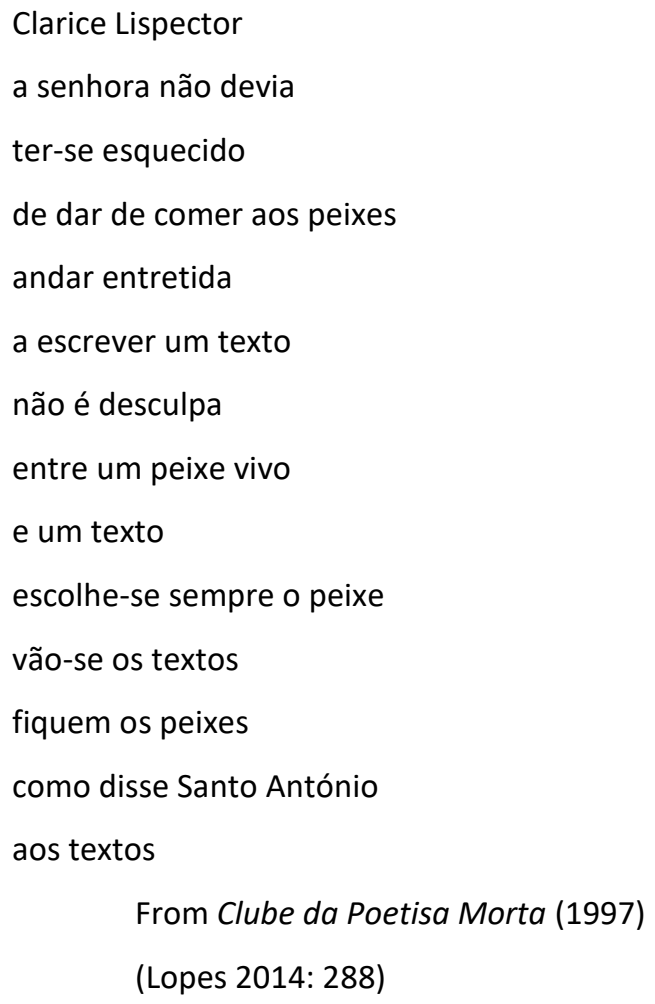

While the ironic tone of the poem is set by the reference to Brazil's canonical writer (and indeed feminine icon) as "a senhora", an ethical current nevertheless flows through the text. The closing four lines of the poem, in which male canonical discourse is re-written, such that the biblical story of Saint Anthony, in which he abandons an inattentive congregation of listeners to go and preach to a school of rapt fish instead, is reformulated, with living matter being privileged over textual matter.

\section{Vibrant Materiality and Mor(t)ality}

Adília's concern for animals extends to the broader natural world. In the vein of ecocriticism and affect theory, the presence of "vibrant materiality" (Bennett, 2010) in Adília's poetry is noteworthy, since it demonstrates how her lyric "I" leans out even to the point of giving presence and voice to inanimate matter:

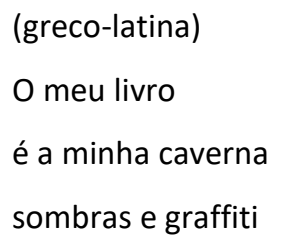




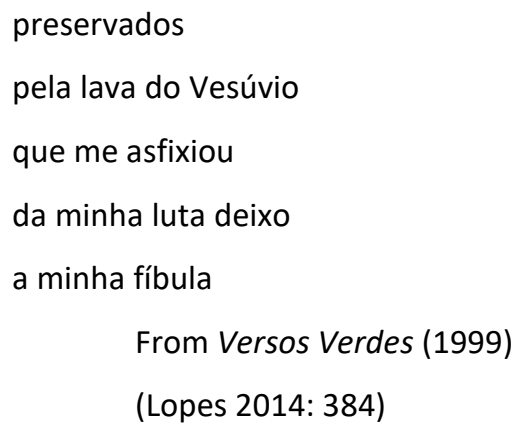

The brevity of the poem, alongside the indication of its "greco-latina" tenor, relates the poem to found fragments of poetry from the Greco-Roman world, such as those by Sappho. The image of the "caverna", full of "sombras e graffiti", calls to mind Plato's allegory of the cave (Republic, 514a-520a), in which the prisoners live in an illusory world, believing that the shadows cast by artefacts, held up to firelight by their keepers, are in fact the true entities of the real world. Adília's poem thereby invokes the notion of the mismatch of appearances versus reality, which in Plato's allegory - as previously noted - is overcome by the philosopher's ascent to the outside realm of Ideas where clarity, reason and truth prevail. Yet while the lexis of textual exposition and biography is invoked by the speaker's claim to be recounting "O meu livro", this expectation is thwarted by the poem's ending, in which what is left to us by the speaker is not a "fábula", a morality tale or fable in the heroic register, but rather her "fibula", evoking the notion of vestiges of the past, but also of bare bones. In other words, where Plato emphasised the mind, Adília inscribes the body, which has its own story of vulnerable human mortality to tell, given that the speaker was asphyxiated by the eruption of Vesuvius. In this sense, the Vesuvian lava, which acts as a conserving agent, and the human calf bone which stimulates the reader's archaeological inquiry into the speaker's life, are depicted as actants, in Bruno Latour's sense, that is as sources of action (human or non-human) which have the efficacy to modify other entities (Bennett, 2010: viii). Adília's poem reminds us that we may learn as much about the world from the vibrantly material traces of suffering and mortality, as from what people actually narrate about human life, whether in chronicles of heroism or moral fables, which abound in Greco-Roman literature. 


\section{Conclusion: The Empathic Fragility of Adília's Lyric “I”}

Adília's work is permeated with this notion of fragility, which is reappraised in a positive light, as a stimulus to ethical awareness. The piece which features as the epigraph to this essay, taken from Irmã Barata, Irmã Batata (2000), is a succinct example of this: "O meu eu, o eu, é frágil, muda e fica, é uma planta". The phrase moves eloquently from an initial assertion of uniqueness, with the use of the possessive pronoun, to the effacement of the self, with its being relinquished. The "eu" is portrayed as vulnerable ("frágil") and mute ("muda"), yet the elision of its idiosyncrasies and absorption into the more general category of selfhood does not wipe away its existence, since it remains ("fica"). Furthermore, the closing metaphor of the self as a plant undermines the common assumption about human mastery over the natural world by highlighting similarities between the plant's material defencelessness ("frágil"), its quietly unobtrusive life ("muda"), and its rootedness ("fica"), on the one hand, and the fragility of the human self, on the other. Additionally, the notion of inclination, in the sense of a slope which may - figuratively speaking - propitiate slippages in meaning, is contained in the polyvalence of the word "muda", which can be read both as an adjective meaning "mute", and as a third-person present tense conjugation of the verb "mudar" ("to move"), conveying a sense of the self as both mute and plant-like, and yet also as mobile. It acts as the fulcrum of the sentence, standing between "frágil" (which can only be an adjective), on the one hand, and "fica" (which can only be a verbal form), on the other. Through the destabilisation of the signifier, it thereby embodies the mutual fecundities of openness and proximity, and related notions of mutation and growth, through its porous absorption of the grammatical qualities of contiguous words within the sentence.

This muteness of the plant-like self, along with its potential mobility, recalls an earlier poem from A Pão e Água de Colónia (1987), the first line of which is "A minha Musa antes de ser". Here the lyric " $I$ " relates the cruelty of her Muse in cutting out her tongue, paradoxically in order that she may learn to sing, thereby imbuing all of her subsequent poetry with a sense of the effacement of the traditional orphic singing poetic personality, in favour of a self which - far from receiving divine inspiration - is instead constituted by its generative, earthly connections to the alterity of other human, animal and plant life. Insofar as Adília's poetry has been considered by many as a "case apart" in Portuguese letters, "um 
"caso» Adília Lopes" as Osvaldo Manuel Silvestre puts it (1999: 37), this does indeed seem to be a consequence of her ongoing critique of forms of poetry reliant on "uma mística secularizada do verbo poético" (1999: 40), and particularly of her deconstruction of the autonomy of the individualistic (lyric) self. The lyric subject of Adília's work is inclined, open, and self-consciously constituted through others, inflected with an ethical model which valorises vulnerability.

While humans are to some extent trapped by the way in which language speaks us, with phallogocentrism's legacy of logic-centred, binary thought ("a gramática é a lógica aplicada", as stated in Irmã Barata, Irmã Batata, 2000 [Lopes 2014: 412]), Adília's critique of uprightness, and ultimately her redemption of materiality and vulnerability from their systematic degradation in Western philosophy, all serve to engender a poetics of inclination, which reorganises affective imperatives to ethical ends. Apprising its readers of the oppressiveness of culturally-dominant, patriarchally-sanctioned rectitude, her poetry opens up plenteous, liberating space for the exploration of feminist and queer inclinations, making visible the hidden commonalities of human and non-human lives and materialities. 


\section{NOTES}

${ }^{1}$ Lyric poetry's traditional privileging of the orphic mode, its exultation of poetic genius, and its evocation of the transcendent beyond of Art, are called into question by the way in which Adília's poetry makes manifest its saturation with social discourse, popular wisdom and cultural narratives, all of which can be said to constitute her model of lyric subjectivity as an amalgamation of the individual and its socio-linguistic-cultural milieu.

2 The use of the word "charitable" in defining Adília Lopes's poetry is suggested to me by the point of view implied in the third section of the poem 'Amo-te' (which reads "Sem caridade/ a literatura/ não vale"), in Sete Rios Entre Campos (Lopes, 2014: 364), as well as the affirmation that "a caridade é a verdadeira inteligência", which appears in Irmã Barata, Irmã Batata (Lopes, 2014: 405).

${ }^{3}$ Much critical literature on Adília Lopes has noted the prevalence of cruelty as a prime thematic concern in her works, including Rosa Maria Martelo in her article 'Childhood Memories in the Poetry of Adília Lopes' where she claims that "cruelty is the major theme in this poet's work" (Blanco / Williams, 2017). Paulo Rego has emphasised the grotesque side of Adília's work, saying: “Adília Lopes é de um grande romantismo e ao mesmo tempo de um grotesco e de um cómico transbordantes" (Rego, 2001).

${ }^{4}$ As Judith Butler has claimed, vulnerability (which may indicate the state of being acted upon against one's will or without one's advance knowledge), along with its related terms "responsiveness, impressionability, susceptibility, injurability, openness, indignation, outrage and resistance", stands in opposition to a growing politics of exclusion (emblematically evidenced in present day anti-migrant sentiment in Europe) which is shored up by the masculinist account of the sovereignty of the self and the state (Butler, 2015).

${ }^{5}$ Klobucka (2000, 2003, 2008, 2009), Silva (2007) and Dal Farra (2015), among others, have shown how Adília's poetry situates itself within a female genealogy through dialogues established with women writers in (para)textual citations, and via her postmodern reworking of the myth of the Portuguese nun Mariana Alcoforado; yet the way in which Adília reimagines the symbolic potential of other fictional female characters from literary tradition, such as Pessoa's heteronym, is worth considering in more detail.

${ }^{6}$ As Martelo has pointed out (2000: 399), Adília publishes both poetry and prose under the collective heading "Poesia", as part of her project of legitimizing "uma escrita desenvolvida [...] como jogo perigosamente conduzido num espaço de distensão das fronteiras entre verso e prosa, entre discurso literário e discurso não literário." 


\section{Bibliography}

\section{Primary Sources:}

Lopes, Adília (2000), Obra, Lisbon, Mariposa Azual.

-- (2014), Dobra: Poesia Reunida, Lisbon, Assírio \& Alvim.

\section{Secondary Sources:}

Ahmed, Sara (2006), Queer Phenomenology: Orientations, Objects, Others, Durham, Duke University Press.

-- (2014), The Cultural Politics of Emotion, $2^{\text {nd }}$ edition, Edinburgh, Edinburgh University Press. Anderson, Linda (1997), Women and Autobiography in the Twentieth Century: Remembered Futures, London, Prentice Hall/Harvester Wheatsheaf.

Atterton, Peter / Matthew Calarco (2004), Animal Philosophy: Essential Readings in Continental Thought, London, Continuum.

Barthes, Roland (1982), A Barthes Reader, London, Jonathan Cape.

Battersby, Christine (1989), Gender and Genius, London, The Women's Press.

Bennett, Jane (2001), The Enchantment of Modern Life: Attachments, Crossings, and Ethics, Princeton, Princeton University Press.

-- (2010), Vibrant Matter: A Political Ecology of Things, Durham, Duke University Press.

Benstock, Shari (1988), The Private Self: Theory and Practice of Women's Autobiographical Writings, London, Routledge.

Blanco, Maria-José / Claire Williams (eds) (2017), Feminine Singular: Women Growing Up through Life-Writing in the Luso-Hispanic World, Oxford/New York, Peter Lang.

Braidotti, Rosi (2011), Nomadic Subjects: Embodiment and Sexual Difference in Contemporary Feminist Theory, $2^{\text {nd }}$ edition, New York, Colombia University Press. 
Butler, Judith (1997), Excitable Speech: A Politics of the Performative, London, Routledge.

-- (2006), Precarious Life: The Powers of Mourning and Violence, London, Verso.

-- (2015), Keynote lecture held at the International conference "How to Act together: From Collective Engagement to Protest" on 20 Nov 2015 in Belgrade, Serbia. Online video recording, YouTube, $20^{\text {th }}$ Nov 2015, <https://www.youtube.com/watch?v=MnA_IAW YXV8> [last accessed 6 Dec 2018].

-- / Zeynep Gambetti / Leticia Sabsay (eds) (2016), Vulnerability in Resistance, Durham and London, Duke University Press.

Cavarero, Adriana (1993), "Towards a theory of sexual difference" in Kemp, Sandra and Paola Bono (eds), The Lonely Mirror: Italian Perspectives On Feminist Theory, London, Routledge, 189-221.

-- (2016), Inclinations: A Critique of Rectitude, Stanford, Stanford University Press.

Coleman, Rebecca (2009), The Becoming of Bodies: Girls, Images, Experience, Manchester, Manchester University Press.

Dal Farra, Maria Lúcia (2016), “O cisne e seu canto: leitura dos poemas de Fiama por Adília Lopes" in: Congresso Internacional de Língua Portuguesa 'Filosofia e Poesia', 2016, Porto, Portugal, Porto, Universidade do Porto, 2015. v. 1., 283-306.

De Courtivron, Isabelle / Elaine Marks (eds) (1980), New French Feminisms: An Anthology, Amherst, University of Massachusetts Press.

Deleuze, Gilles / Félix Guattari (1986), Kafka: Toward a Minor Literature, translation by Dana Polan, London, University of Minnesota Press.

Diogo, Américo António Lindeza (2000), "Posfácio", in Lopes, Adília, Obra, Lisbon, Mariposa Azual, 475-494.

Donovan, Josephine (2016), The Aesthetics of Care: On the Literary Treatment of Animals, New York/London, Bloomsbury.

Dubreuil, Laurent (2018), Poetry and Mind: Tractatus Poetico-Philosophicus, New York, Fordham University Press. 
Engelmayer, Elfriede (2000), "Posfácio", in Lopes, Adília, Obra, Lisbon, Mariposa Azual, 469472.

Espanca, Florbela (2012), Livro de Mágoas, edited by Pazos-Alonso, Cláudia / Fabio Mario da Silva, Lisbon, Editorial Estampa [1919].

Esposito, Roberto (2011), The Protection and Negation of Life, translation by Zakiya Manafi, Cambridge, Polity Press.

Freud, Sigmund (1961), Civilization and its Discontents (revised edition by James Strachey), translation by Joan Riviere. London: Hogarth Press; Institute of Psycho-Analysis [1930].

Gottlieb, Sidney / Christopher Brookhouse (2002), Framing Hitchcock: Selected Essays from the 'Hitchcock Annual', Detroit, Wayne State University Press.

Grosz. Elizabeth (1994), Volatile Bodies: Toward a Corporeal Feminism, Bloomington, Indiana University Press.

Keller. Lynn (2010), Thinking Poetry: Readings in Contemporary Women's Exploratory Poetics, lowa City, University of lowa Press.

Keller. Lynn / Cristanne Miller, (eds) (1994), Feminist Measures: Soundings in Poetry and Theory, Ann Arbor, The University of Michigan Press.

Klobucka, Anna M (2000), The Portuguese Nun: Formation of a National Myth, Lewisburg, Bucknell University Press.

-- (2003), “Spanking Florbela: Adília Lopes and a Genealogy of Feminist Parody in Portuguese Poetry", Portuguese Studies n. 19 (1 Jan 2003), 190-204.

-- (2008), "Sobre a hipótese de uma herstory da literatura portuguesa", Veredas: Revista da Associação Internacional de Lusitanistas n. 10 (1 Dec 2008), 13-25.

-- (2009), O Formato Mulher: A Emergência da Autoria Feminina na Poesia Portuguesa, Coimbra, Angelus Novus.

Lecercle, Jean-Jacques / Denise Riley (2004), The Force of Language, New York, Palgrave MacMillan. 
Lispector, Clarice (2017), A mulher que matou os peixes, Rio de Janeiro, Rocco Pequenos Leitores.

Martelo, Rosa Maria (2000), “Adília Lopes, Obra”, Colóquio/Letras 157/158 (July-December 2000), 398-401.

-- (2010a), "Contra a crueldade, a ironia", in Martelo, Rosa Maria, A Forma Informe - leituras de poesia, Lisbon, Assírio \& Alvim, 223-234.

-- (2010b), "As armas desarmantes de Adília Lopes", in Martelo, Rosa Maria, A Forma Informe - leituras de poesia, Lisbon, Assírio \& Alvim, 235-252.

Massumi, Brian (2015), Politics of Affect, Cambridge, Polity.

Midgley, Mary (1983), Animals and Why They Matter: A Journey Around the Species Barrier, Harmondsworth, Penguin.

-- (2004), The Myths We Live By, London, Routledge.

Mitchell, W.J.T. (1994), Picture Theory: Essays on Verbal and Visual Representation, Chicago, The University of Chicago Press.

Owen, Hilary / Cláudia Pazos-Alonso (2009), "Women Writers up to 1974" in Parkinson, Stephen et al., A Companion to Portuguese Literature, Woodbridge, Tamesis.

Pedrosa, Célia (2009), “De Espelhos e Demônios: A poesia de Adília Lopes e o Imaginário Europeu", Portuguese Cultural Studies Vol. 2 (Winter 2009), Issue 1, Article 2.

Plato (1998), Republic, translation by Robin Waterfield, New York, Oxford University Press.

Rego, Paula (2001), Sobre Adília Lopes: "No grotesco há muita ternura", Público, $10^{\text {th }}$ Feb 2001, Suplemento Mil Folhas.

Riley, Denise (2005), Impersonal Passion: Language as Affect, Durham/London, Duke University Press.

Sedgwick, Eve Kosofsky (2003), Touching Feeling: Affect, Pedagogy, Performativity, Durham/London, Duke University Press.

Sedgwick, Eve Kosofsky / Adam Frank (eds) (1995), Shame and Its Sisters: A Silvan Tomkins Reader, Durham/London, Duke University Press. 
Silva, Sofia Maria de Sousa (2007), "Reparar brechas: a relação entre as artes poéticas de Sophia de Mello Breyner Andresen e Adília Lopes e a tradição moderna", Tese de Doutorado, Pontifícia Universidade Católica do Rio de Janeiro, digital copy.

Silvestre, Osvaldo Manuel (1999), "As lenga-lengas da menina Adília", in Lopes, Adília, Florbela Espanca Espanca, Lisbon, Black Sun Editores, 37-77.

Souza, Phabulo Mendes de (2014), "A tessitura poética de Adília Lopes". Dissertação de mestrado. Universidade de São Paulo (USP), digital copy.

Warner, Marina (1985), Monuments and Maidens: The Allegory of the Female Form, London, Pan Books Ltd.

-- (1990), Alone of All Her Sex. The myth and cult of the Virgin Mary, London, Picador.

Andrzej Stuart-Thompson is a first-year DPhil student in Modern and Medieval Languages (Portuguese) at Jesus College, University of Oxford. His research interests include twentieth and twenty-first century Portuguese women's poetry; the culturally- and linguisticallyhybridised prose works of Angolan resistance writer José Luandino Vieira; and the positive valorisation of vulnerability as a form of resistance to certain patriarchal ideals. His DPhil research project envisages an examination of the richly ambiguous anti-epic poetry of Natália Correia, Luiza Neto Jorge and Ana Luísa Amaral in relation to the Portuguese canon. 